\title{
ABSORPTION OF THE HORSE-RADISH PEROXIDASE IN THE SMALL INTESTINE OF CHICKEN
}

\author{
J. HOLMAN \\ Department of Electron Microscopy, University of Veterinary Science, 61242 Brno
}

Received Fanuary 13, 1978

\begin{abstract}
Holman J.: Absorption of the Horse-radish Peroxidase in the Small Intestine of Chicken. Acta vet. Brno, 47, 1978: 3-6.

Localization of the horse-radish peroxidase was studied in the epithelium and stroma of the small intestinal villi in the chic's aged 37 days. The enzyme (molecular weight 40.000 ) was injected into the ligated jejunal loop. Its enteral absorption was shown to proceed via the senescent ent.rucytes.

After the 3- and 5-minute long exposure the enzyme occurred in the epithelial terminal web and in the cytoplasm of senescent enterocytes. After the 10- and 20-minute long exposure the enzyme was shown in the vicinity of the basement membrane of the epithelium and near the blood vessels of the villous stroma. After the 30-minute exposure the horse-radish peroxidase was found in the intercellular spaces at the tips of the intestinal villi.
\end{abstract}

Small intestine, senescent enterocyte, macromolecular transport.

Horse-radish peroxidase is an important labelling material employed in research of transport of high-molecular substances. The enzyme can be visualized by both light and electron microscope and its amount can be quantitatively determined also in extremely small concentrations.

Besides the well-known enzymatic digestion of food macromolecules, e. g. proteins, prior to their absorption by the small intestinal mucosa there is some evidence to indicate that through the adult intestinal wall small and nutritionally unimportant amounts of intact molecules can pass (Alexander et al. 1936; Danforth and Moore 1959). In other biochemical experiments free transfer of intravenously injected or endogenous proteins through the intestinal mucosa was observed (Wettefors et al. 1960; Campbell et al. 1961; Ghettie et al. 1967).

All experiments studying the absorption of horse-radish peroxidase by the intestinal mucosa have been made on mammals (rats, mice) and evaluated by both the light and electron microscope. Hugon and Borgers (1968) and Hugon (1971) at i. v. or i. p. injection of peroxidase found the labelling substance to diffusely stain the cytoplasm of some absorptive cells. The other absorptive cells of the villous epithelium and of the crypts accumulated peroxidase in their apical parts. Cornell et al. (1971) found that after the intraluminal injection of peroxidase into the ligated jejunal or ileal segment of an adult rat the exogenous macromolecule can be transported into the intestinal absorptive cell by its typical vacuolar system and it can be transferred by these cells into the intercellular space of the lamina propria mucosae. The intestinal epithelial cells with diffusely staining cytoplasm are eonsidered to be senescent enterocytes. Ono (1975) electronmicroscopically localized the exogenous peroxidase after its intraluminal application in the small intestinal epithelium of rats during their postnatal development.

The aim of the present work was to find the absorption sites of the exogenous protein (horse-radish peroxidase) in the jejunum of the chicken.

\section{Materials and Methods}

In the experiment White Leghorn chickens aged 37 days were employed. After a 24-hour long fast, through an incision the jejunal loop near the Meckel's diverticulum was exteriorized and ligated at two places. Under low pressure the horse-radish peroxidase (molecular weight 40.000) 
1.11.1.7 - Serva, Heidelberg, was injected into the ligated jejunal loop at the dose of $1 \mathrm{mg}$ in $0.5 \mathrm{ml}$ saline. The ligated intestinal segment was returned into the body cavity and the incision was sutured. The intestinal wall samples were collected $3,5,10,20$ and 30 minutes after the peroxidase injection.

Small pieces of intestinal tissue were fixed in $3 \%$ glutaraldehyde in $0.1 \mathrm{M}$ cacodylate buffer ( $\mathrm{pH}$ 7.3) for 2 hours at $4{ }^{\circ} \mathrm{C}$. The samples were washed overnight in $0.1 \mathrm{M}$ cacodylate buffer with $4.8 \%$ saccharose and incubated in the medium by Graham and Karnovsky (1966) for 30 minutes. After a short washing in the same buffer the samples were embedded in paraffin. The peroxidase reaction was evaluated on the counterstained paraffin sections, and on those stained with hematoxylin before mounting into the canadian balsam.

The control sections were obtained from tissue incubated in the incomplete medium and also from birds which had their ligated intestinal loop injected with saline. Samples from these chickens were incubated in the complete medium.

\section{Results}

After the 3- and 5-minute exposure of the ligated jejunal loop to the intestinal contents with $1 \mathrm{mg}$ exogenous peroxidase the enzyme was localized in the cuticular rim of the tips of jejunal villi and in the cytoplasm of senescent enterocytes (Plate I, Fig. 1).

After the 10-minute exposure the enzyme reached deeper into the epithelium and it was found near the basement membrane and blood capillaries of the villous stroma. The senescent enterocytes were filled with exogenous peroxidase. The apical portion of these cells stained usually more intensively than their basal part (Plate I, Fig. 2).

After the 20-minute exposure of the ligated jejunal loop to the exogenous peroxidase high activity of the enzyme was found in the vicinity of and in the wall of the blood capillaries at the villous tips (Plate II, Fig. 3).

After the 30-minute exposure the enzyme was present in the cytoplasm of senescent enterocytes, in the vicinity of and in the wall of blood capillaries in the stroma of the villous tips (Plate II, Fig. 4). In addition, it was found in the epithelial intercellular space.

\section{Discussion}

The exogenous peroxidase applied into the contents of the ligated intestinal loop at the dose of $1 \mathrm{mg}$ is not absorbed by the active enterocytes of chicken intestinal villi as clearly evidenced by the present work. The enzyme enters the intestinal epithelium and villous stroma exclusively through the senescent enterocytes. The majority of similar previous experiments made on mammals showed the enterocytes to absorb the intraluminally applied exogenous peroxidase. Cornell et al. (1971) found the exogenous peroxidase injected into the ligated jejunal and ileal loops at a dose of $5 \mathrm{mg}$ to be absorbed within 5 minutes into the microvilli, vacuolar system of enterocytes and intracellular spaces. Similar results in weaned and adult rats were obtained by Ono (1975) after the application of $20 \mathrm{mg}$ exogenous peroxidase. The author collected samples from the ligated intestinal loops at 30, 60, 120 and 180 minutes. Presence of the exogenous peroxidase in the dense bodies of enterocytes was shown after the $i$. v. injection of peroxidase to mice (Hugon and Borgers 1968). Peroxidase was present in the terminal web and in the deep invaginations of the apical membrane of enterocytes also after peroral administration of $9 \mathrm{mg}$ of the enzyme to 10-day-old mice (Hugon 1971). Authors of the two last-mentioned papers draw attention to the fact that the peroxidase given $i$. v. and p. o. stains diffusely some cells in the intestinal epithelium and it rapidly diffuses into the intercellular space. 
The differences in absorption of the exogenous peroxidase between the birds and mammals can be explained by species specifities. Evidence of different absorption rate of exogenous protein and colloidal substance in the individual small intestinal segments in suckling rats and mice was brought by Clark (1959). In the present experiment the exclusive absorption of horse-radish peroxidase by the senescent enterocytes might have been caused by the low dose $(1 \mathrm{mg})$ of the enzyme. This amount was probably quickly absorbed by the senescent enterocytes at the tips of the jejunal villi so that the active and functional enterocytes received no material to absorb. The senescent cells absorb readily the exogenous horse-radish peroxidase as evidenced by several authors (Hugon and Borgers 1968; Hugon 1971; Cornell et al. 1971). The plasma membrane of these cells is probably changed already in early stages of senescence (Potten and Allen 1977) or its integrity is impaired (Holman 1975).

\section{Resorpce křenové peroxidasy tenkým střevem kuřete}

Po aplikaci $1 \mathrm{mg}$ peroxidasy $\mathrm{z}$ křenu do ligované kličky jejuna 37 dní starého kuřete byla histochemicky studována lokalizace enzymu $\mathrm{v}$ epitelu a stromatu střevních klků.

Peroxidasa z křenu (molekulární váha 40000 ) byla enterálně vstřebávána prostřednictvím stárnoucích enterocytů.

Již po 3-5 min. exposici byl enzym lokalizován $\mathrm{v}$ kutikulovém lemu epitelu a v cytoplasmě stárnoucích enterocytů. Po $10-20 \mathrm{~min}$. exposici byl enzym prokázán v blízkosti basální membrány epitelu a v blízkosti krevních kapilár stromatů klků. Po $30 \mathrm{~min}$. exposici se enzym shromaždoval $\mathrm{v}$ mezibuněčných prostorech epitelu vrcholu střevních klků.

\section{Резорбция пероксидазы хрена тонкой кишкой цыпленка}

После применения 1 мг пероксидазы из хрена в перевязанную петлю тощей кишки цыпленка в возрасте 37 дней проводилось гистохимическое изучение наличия энзима в эпителии и строме кишечных ворсинок.

Пероксидаза из хрена (молекулярный вес 40.000) энтерально рассасывалась посредством стареющих энтероцитов.

Уже после экспозиции продолжительностью 3-5 мин энзим был определен в кутикульной каемке эпителия и в цитоплазме стареющих энтероцитов. После экспозиции 10-20 минут энзим был выявлен поблизости базальной мембраны эпителия и недалеко кровеносных капилляр стромы ворсинок. После экспозиции продолжительностью 30 минут энзим накоплялся в межклеточных пространствах эпителия вершины кишечных ворсинок.

\section{References}

ALEXANDER, H. L. - SHIRLEY, K. - ALLEN, D.: The route of ingested egg white to the systemic circulation. J. Clin. Invest., 15, 1936: 163.

CAMPBELL, R. M. - CUTBERTSON, D. P. - MACKIE, N. - McFARLANE, A. S. PHILLIPSON, A. T. - SUDSANEH, S.: Passage of plasma albumin into the intestine of the sheep. J. Physiol. (London) 158, 1961: 113.

CLARK, S. L. Jr.: The ingestion of proteins and colloidal materials by columnar absorptive cells of the small intestine in suckling rats and mice. J. Biophysic. Biochem. Cytol., 5, 1959: $41-50$. 
CORNELL, R. - WALKER, W. A. - ISSELBACHER, K. J.: Small intestinal absorption of horseradish peroxidase. A cytochemical study. Lab. Invest. J. Pathol., 25, 1971: 42-48.

DANFORTH, E. Jr. - MOORE, R. O.: Intestinal absorption of insulin in the rat. Endocrinology, 65, 1959: 118.

GHETIE, V. - MEDESAN, C. - CHISIU, N. S.: Retention and degradation of fluorescent human albumin by the small intestine of rats perfused in situ. Rev. Roum. Biochim., 4, 1967: 119.

GRAHAM, R. C. - KARNOVSKY, M. J.: The early stages of absorption of injected horseradish peroxidase in the proximal tubules of mouse kidney: Ultrastructural cytochemistry by a new technique. J. Histochem. Cytochem., 14, 1966: 291-302.

HOLMAN, J.: Fine structural changes of senescent enterocytes in the extrusion zone of chicken intestinal villi. Acta vet. Brno, 44, 1975: 3-8.

HUGON, J: S.: Absorption of horse-radish peroxidase by the mucosal cells of the duodenum of mouse. Histochemie, 26, 1971: 19-27.

HUGON, J. S. - BORGERS, M.: Absorption of horseradish peroxidase by the mucosal cells of the duodenum of mouse. I. The fasting animal. J. Histochem. Cytochem., 16, 1968: 229-236.

ONO, K.: Absorption of horseradish peroxidase by the small intestinal epithelium in postnatal developing rats. Z. mikrosk.-anat. Forsch., 89, 1975: 870-883.

POTTEN, C. S. - ALLEN, T. D.: Ultrastructure of cell loss in intestinal mucosa. J. Ultrastructure Res., 60, 1977: 272.

WETTEFORS, J. - GULlBERG, R. - LILJEDAIL, S. O. - PLATIN, L. O. - BIRKE, G. - OLHAGEN, B.: Role of the stomach and small intestine in albumin breakdown. Acta Med. Scand., 168, 1960: 347. 